\title{
Associations between milk protein concentration at various stages of lactation and reproductive performance in dairy cows
}

\author{
J. M. Morton, ${ }^{* 1}$ M. J. Auldist, $†$ M. L. Douglas, $†$ and K. L. Macmillan $\ddagger$ \\ *Jemora Pty Ltd., Geelong, Victoria 3220, Australia \\ †Department of Economic Development, Jobs, Transport and Resources, Ellinbank Centre, Victoria 3821, Australia \\ ‡Department of Veterinary and Agricultural Sciences, The University of Melbourne, 250 Princes Highway, Werribee, Victoria 3030, Australia
}

\begin{abstract}
Milk protein concentration has been positively associated with a range of measures of reproductive performance in dairy cows. These beneficial associations are most likely due to factors affecting both milk protein concentration and reproductive performance possibly being mediated, in part, by energy balance during early lactation. However, it is likely that factors other than energy balance are also involved in these relationships. A retrospective single cohort study was conducted using subsets of data collected from 74 dairy herds with seasonal or split calving patterns. Associations between milk protein concentration at various stages of lactation and reproductive performance in Holstein dairy cows were assessed using random effects logistic regression and survival analysis with milk protein concentration during the cow's breeding period fitted as a timevarying covariate. The beneficial associations between milk protein concentration and each of the 4 selected indices for measuring reproductive performance were evident when milk protein concentration was derived for each $30-\mathrm{d}$ period from calving up to $300 \mathrm{~d}$ in milk. For the first $150 \mathrm{~d}$ of lactation the adjusted odds ratios were highest from 31 to $60 \mathrm{~d}$ and only slightly lower for all periods up to $150 \mathrm{~d}$ of lactation. Estimated associations for 31 to $60 \mathrm{~d}$ were stronger than for 0 to $30 \mathrm{~d}$. In addition, milk protein concentration during a cow's breeding period was positively associated with the subsequent daily hazard of conception, even after adjusting for milk protein concentration in the cow's first or second month of lactation. Milk protein concentrations from 0 to $30 \mathrm{~d}$ of lactation were less closely correlated with concentrations measured at subsequent $30-\mathrm{d}$ intervals; correlations were closer between other periods in lactation. These results indicate that the association between milk protein concentration and reproductive performance is partly due to factors other than the
\end{abstract}

Received April 5, 2016.

Accepted August 3, 2016.

${ }^{1}$ Corresponding author: john.morton@optusnet.com.au extent of negative energy balance in early lactation. However, it is possible that energy balance accounts for some of the relationship as the magnitude and direction of energy balance can vary within and between cows throughout lactation. Factors determining milk protein concentration during the first $30 \mathrm{~d}$ of lactation are not identical to the causes of milk protein concentration later in lactation, and some of the latter causes of milk protein concentration may be more closely related to the underlying mechanisms contributing to the milk protein concentration-reproductive performance relationship. Milk protein concentrations from a single test day from any day of lactation predict subpopulations of cows with differing average reproductive performance; milk protein concentrations measured after $30 \mathrm{~d}$ of lactation are more useful than concentrations measured in the first $30 \mathrm{~d}$ for identifying these subpopulations. Further research is required to identify the causes of these associations.

Key words: milk protein concentration, reproductive performance, dairy cow

\section{INTRODUCTION}

Milk protein concentration has been positively associated with a range of measures of reproductive performance in dairy cows in both year-round calving herds (Opsomer et al., 2000; Moss et al., 2002; Madouasse et al., 2010) and pasture-based, seasonally calving herds in Ireland (Patton et al., 2007; Yang et al., 2009), New Zealand (Xu and Burton, 2003; Harris and Pryce, 2004), and Australia (Fahey et al., 2003; Morton, 2004). These positive associations have also been reported in strains of Holstein-Friesians, with marked differences in milk yields and reproductive performance (Patton et al., 2007; Yang et al., 2009), and are most likely to be due to factors affecting both milk protein concentration and reproductive performance. They are thought to be mediated, in part, by energy balance during early lactation (Yang et al., 2009; Madouasse et al., 2010). This hypothesis arises because milk protein concentration during the first 3 mo of lactation is 
higher in cows with better (i.e., less negative) energy balance (Grieve et al., 1986; Garvin, 1999) and more severe negative energy balance has adverse effects on reproductive performance (Canfield et al., 1990; Reist et al., 2003; Patton et al., 2007). Factors other than energy balance during early lactation may also contribute to these relationships. Milk protein concentration for the whole lactation has been positively associated with reproductive performance (Buckley et al., 2003; Harris and Pryce, 2004; Yang et al., 2009), even though negative energy balance is mostly confined to early lactation (de Vries and Veerkamp, 2000; Coffey et al., 2004; Friggens et al., 2007; Pedernera et al., 2008) when milk protein concentrations are more variable (Silvestre et al., 2009). The whole of lactation associations are also of particular interest, as milk protein concentration in early lactation is not closely correlated with milk protein concentrations in mid and late lactation (Haile-Mariam and Goddard, 2008). Further, milk protein concentration in first-lactation heifers is associated with their first calving date (J. Fahey, Department of Veterinary Science, University of Melbourne, Victorian Institute of Animal Science, Werribee, Victoria, Australia, personal communication), reflecting their reproductive performance as yearlings, a period when mechanisms related to lactation would not occur and when negative energy balance would not be expected. Although energy must be partitioned to the udder for production of milk protein (Hanigan et al., 2001, 2002), milk protein synthesis is complex, also being affected by availability of EAA (Lapierre et al., 2012). In addition, milk protein concentration is determined not just by the rate of production of milk protein but also by milk volume, which, in turn, is determined by rate of lactose synthesis (Hanigan et al., 2001). Milk protein concentration responses to increased energy intake are small (Coulon and Rémond, 1991), suggesting that concentrations are determined by major mechanisms other than dietary energy supply.

Because the extent of negative energy balance reduces as lactation progresses, if the association between milk protein concentration and reproductive performance is primarily caused by negative energy balance in early lactation, the association when milk protein concentration is assessed after early lactation should be weaker. No previous study has systematically compared strengths of associations between milk protein concentration measured throughout lactation and a range of reproductive measures. This knowledge could help our understanding of the biology of the associations. In addition, milk protein concentration could be used as an indicator of likely reproductive performance for herd management purposes, such as selecting cows most likely to conceive to inseminations with expensive or sexed semen. For the greatest predictive accuracy, it would be preferable to use milk protein concentration data derived from the stage or stages of lactation when it has the strongest positive association with measures of reproductive performance.

The objective of our study was to assess the strengths of associations between milk protein concentration at various stages of lactation and selected measures of reproductive performance in Holstein cows in pasturebased, seasonally and split-calving dairy herds, and to assess associations between milk protein concentration during each cow's breeding period and subsequent hazard of conception.

\section{MATERIALS AND METHODS}

\section{Study Overview}

A retrospective single cohort study was conducted using subsets of data collected from 74 seasonally and split-calving dairy herds. Associations between milk protein concentration at various stages of lactation and reproductive performance in Holstein cows were assessed using random effects logistic regression and survival analysis, with milk protein concentrations during each cow's breeding period fitted as a time-varying covariate.

Calvings in seasonally calving dairy herds occur within a short period each year, and inseminations occur from the breeding period start date, the calendar date that is $282 \mathrm{~d}$ (i.e., one gestation length) before the herd manager plans the next calving period to commence. Typically, AI is used exclusively for 4 to $8 \mathrm{wk}$, and then bulls graze with the lactating herd for a further period. In split-calving study herds, all calvings each year occurred within 2 or 3 distinct temporal periods commencing 4 to 8 mo apart. These herds have 2 or 3 distinct breeding periods, each commencing with a breeding period start date that is $282 \mathrm{~d}$ before the desired commencement date for the corresponding calving period.

\section{Herd Selection}

In 2010, 58 commercial dairy herds that met the study's herd-selection criteria were selected from clients of each of 4 veterinary practices in Victoria and Tasmania. For the 2009 calving period (or, for split-calving herds, for the largest calving group in 2009), wholeherd rectal pregnancy tested within 17 wk after the breeding period start date using rectal ultrasound or manual examination must have been conducted, with cows not diagnosed pregnant retested after the end of the breeding period. In addition, herds were only se- 
lected if calvings, AI, pregnancy test results along with estimated stages of pregnancy, and removals from the herd through sale, culling, or death, had been entered in the practice database and were considered complete and accurate. Preference was given to herds with records for milk production, induced calvings, and years of birth, as well as with suitable data in multiple years up to 2009. Veterinarians were asked to not consider comparative reproductive performance, milk yield, breed, or herd size when selecting herds.

In addition, all herd-years with sufficient early pregnancy test data in the Australian Dairy Herd Improvement Scheme (ADHIS; www.adhis.com.au) national database for calculation of 6 -wk pregnancy rates were identified. These were herd-years where at least $80 \%$ of cows that calved in the 12 -mo period had pregnancy test results, and at least $80 \%$ of these pregnancy tests were either (a) diagnoses of pregnancy and the estimated stage of pregnancy was 17 wk or less, or (b) nonpositive pregnancy diagnoses. Of these, 20 herds had 6 -wk in-calf rates based on early pregnancy test data for at least 5 of the 6 yr from 2004 to 2009, inclusive; all were selected and their data obtained from ADHIS. Four of these 20 herds were also represented in the 58 herds enrolled by the veterinarians, meaning that 74 distinct herds were finally enrolled.

\section{Determination of Breeding Period Start and End Dates}

Most study herds used AI exclusively for some weeks before running bulls with the herd. Breeding period start dates were determined within each herd based on daily numbers of services (i.e., AI and any recorded bull services).

Dates when bulls were removed from the lactating herds and bull services were generally not recorded. End dates for breeding periods were defined based on conception dates derived from pregnancy testing.

\section{Conception Date Determination}

Conception dates were determined from results of rectal ultrasound or manual pregnancy diagnoses. Conception was assumed to have occurred only if a positive pregnancy diagnosis was made. If more than 1 positive pregnancy diagnosis was recorded, the conception date as estimated at the first positive pregnancy diagnosis was used.

When positive pregnancy diagnoses were entered into the software at the 4 veterinary practices, the user was prompted to either select a previously recorded service as the conception date or create a new service date. For data from the ADHIS national database, for some cows no service was recorded on the date of pregnancy diagnosis minus estimated number of days pregnant. In these cases, the next service within $14 \mathrm{~d}$ after that date was set as the conception date. Where no such insemination or service occurred, conception date was defined as the most recent recorded service on or within $10 \mathrm{~d}$ before that date. If no such service occurred, conception date was defined as date of pregnancy diagnosis minus estimated number of days pregnant on that date.

\section{Lactation Selection and Breeding Period Start Date Allocation}

Only lactations by Holstein cows were included in the current study. Lactations commencing with calvings on or between $120 \mathrm{~d}$ before and $30 \mathrm{~d}$ after the nearest breeding period start date were selected. Lactations were allocated the nearest breeding period start date, except where the next breeding period start date was $120 \mathrm{~d}$ or less later as occurred in some split-calving herds. In this case, lactations commencing with calvings after the first of the 2 breeding period start dates were allocated the second breeding period start date. We assumed herd managers aimed to have these cows conceive in the associated breeding period. Other lactations were excluded from analyses. Lactations where arbitrary calving dates had been recorded (e.g., all calvings for the herd recorded as occurring on the first day of the calendar month) were also excluded from analyses, as were lactations with services or conception dates before the breeding period start date.

\section{Identification of Breeding Periods with Adequate Data for Analysis}

Breeding periods were considered to have adequate data for analyses only if they had more than 50 associated lactations and the cows had at least 1 pregnancy diagnosis for more than $80 \%$ of those lactations.

\section{Reproductive Performance Measures and Lactation Selection}

Four lactation-level binary reproductive performance measures were used. The reproductive performance measures and criteria for calculation are defined in Table 1. Criteria for calculation included minimum time at risk of service or conception. The time that a cow was at risk of receiving her first service for the lactation was calculated as the earliest of culling date and end of breeding period date minus breeding start date plus $1 \mathrm{~d}$. Time at risk of conception occurring and being detected was calculated only for lactations with at least 1 pregnancy diagnosis as last pregnancy 
Table 1. Reproductive measures definitions and criteria for calculation

\begin{tabular}{|c|c|c|}
\hline Measure & Description of event & Criteria for calculation \\
\hline Conceived to first service & $\begin{array}{l}\text { Cow conceived to her first service for } \\
\text { the lactation }\end{array}$ & $\begin{array}{l}\text { The cow was inseminated or served naturally at least } \\
\text { once during that lactation and her first service for } \\
\text { the lactation was by AI and either the cow did not } \\
\text { conceive during that lactation and her most recent } \\
\text { pregnancy test date for the lactation was at least } 28 \\
\text { d after her first service date or the cow conceived } \\
\text { during that lactation }\end{array}$ \\
\hline Pregnancy by wk 6 of the breeding period & $\begin{array}{l}\text { Cow was diagnosed as having } \\
\text { conceived on or between breeding } \\
\text { period start date }(\mathrm{d} 1) \text { and } \mathrm{d} 42 \text { (the } \\
\text { end of wk } 6 \text { ) of the breeding period }\end{array}$ & $\begin{array}{l}\text { Breeding period duration for herd was at least } 42 \mathrm{~d} \\
\text { and either the cow conceived during that lactation } \\
\text { or if not, she was at risk of conception occurring and } \\
\text { being detected until at least d } 42\end{array}$ \\
\hline
\end{tabular}

diagnosis date minus 28 minus breeding period start date plus $1 \mathrm{~d}$ (this assumed that all pregnancies that were aged more than $28 \mathrm{~d}$ at pregnancy testing were detected.) Accordingly, lactations with no pregnancy diagnoses were excluded from calculations of conceived to first service, pregnant by $6 \mathrm{wk}$, and pregnancy by wk 21. For each reproductive measure, lactations were included if the measure could be calculated.

\section{Milk Protein and Fat Concentrations}

Milk protein and fat concentrations had been assessed by commercial milk recording services. Milk recording was generally conducted in one 24 -h period each 4 to 8 wk. Test-day records where 1 or more liters of milk, protein or fat yield were 0 or not recorded were excluded. Using the remaining test-day records for analyses of milk protein and fat concentrations by stage of lactation category, the first test day within each of the following time periods were used: 0 to 30,31 to 60 , 61 to 90 , and so on to 271 to $300 \mathrm{~d}$. For analyses of effects of stage of lactation and conception date on milk protein concentration, all test-day records were used. For survival analyses, all test-day records before each cow's conception or right-censor date were considered. Analyses were restricted to those where milk protein concentration for selected test days were less than $8 \%$.

\section{Numbers of Herds and Lactations}

Of the 74 enrolled herds, 1 was subsequently excluded as substantial numbers of cows and calvings had not been entered into the database. The remaining 73 herds provided data for 126,277 cows; these cows had 359,892 calvings (and hence lactations) recorded. Sequential exclusions were as follows:

- lactations not commencing on or between $120 \mathrm{~d}$ before and $30 \mathrm{~d}$ after each breeding period start date $(\mathrm{n}=86,824$, leaving 273,068$)$;

- duplicated lactations ( $\mathrm{n}=4,246$, leaving 268,822 );

- breeding period did not have adequate data for analyses ( $\mathrm{n}=84,371$, leaving 184,451);

- all lactations allocated to 4 breeding periods where arbitrary calving dates had been recorded ( $\mathrm{n}=1,362$, leaving 183,089);

- cow not recorded as Holstein ( $\mathrm{n}=94,594$, leaving 88,495);

- date of birth not recorded for cow ( $\mathrm{n}=1,343$, leaving 87,152);

- reproductive outcome could not be determined (for pregnancy by wk $6, \mathrm{n}=2,731$, leaving 84,421 ); and

- milk protein concentration not available for particular stage of lactation or $\geq 8 \%$ (for 0 to $30 \mathrm{~d}$ of lactation, $\mathrm{n}=47,851$, leaving 36,570).

Consequently, 36,570 lactation records were used for analyses of the association between milk protein concentration for 0 to $30 \mathrm{~d}$ of lactation and pregnancy by wk 6 . These lactations were from 18,720 cows in 62 herds. For these lactations, the distribution of ages at calving were: $2 \mathrm{yr}=21 \%$ or 7,$537 ; 3 \mathrm{yr}=19 \%$ or 6,$913 ; 4 \mathrm{yr}=17 \%$ or 6,$138 ; 5$ to $7 \mathrm{yr}=31 \%$ or 11,462 ; and 8 yr or older $=12 \%$ or 4,520 . Numbers varied for milk protein concentrations at other stages of lactation and for other reproductive outcomes. Of these 36,570 records with milk protein concentration assessed during 
d 0 to 30 of lactation, $0.27,0.65,1.15,1.56,19.0,36.9$, and $40.4 \%$ of these were from d $0,1,2,3,4$ to 10,11 to 20 , and 21 to 30 , respectively.

\section{Statistical Methods}

Analyses were completed using Stata (version 13, StataCorp, College Station, TX). Effects of month of lactation on milk protein concentration were assessed using a multilevel model with month of lactation clustered within lactation within cow within herd. A firstorder autoregressive correlation structure was fitted for the within-lactation errors. This model was fitted using the mixed command in Stata. $P$-values were adjusted for multiple pairwise comparisons using Bonferroni's method.

Correlations within lactation between milk protein concentrations measured at various stages of lactation were assessed using Pearson correlation coefficients using the pwcorr command in Stata. Correlations between milk protein concentration and fat concentration were assessed within each same stage of lactation in the same way.

Linearity in the logit between milk protein concentration at each stage of lactation and each of the 4 reproductive outcomes (Table 1) was determined by visual assessment of lowess (locally weighted regression) plots after lowess regression of each reproductive outcome on milk protein concentration; smoothed probabilities were transformed into logits before plotting. Stata's lowess command was used for these assessments. Associations between milk protein concentrations and each reproductive outcome were assessed separately for each stage of lactation using random effects logistic regression, with herd fitted as a random effect using the xtlogit command in Stata. Milk protein concentration was fitted as quintile categories and in separate models as a continuous variable. Cows not milk-recorded in particular stages of lactation were excluded from analyses of those stages. Cow's age at calving, source of data, year of breeding period start date, and interval from calving to breeding period start date (linear and quadratic terms) were fitted as fixed effects to remove any confounding due to these variables. Linear and quadratic terms for calving to breeding period start date were replaced with linear and quadratic terms for calving to service interval for analyses of conceived to first service. Intervals from calving to breeding period start date (for submitted by wk 3, pregnant by wk 6 , and pregnant by wk 21) and intervals to service (for conceived to first service) are strong determinants of the 4 reproductive outcomes (Morton, 2004). Hence, even weak correlations between milk protein concentrations and these outcome variables could cause important confounding. As they have curvilinear relationships with submitted by wk 3, conceived to first service, and pregnant by wk 6 (Morton, 2004), quadratic terms were included in all models. Source of data had 7 categories: each of the 4 veterinary practices and, for herds sourced from ADHIS, the herd's region (Gippsland, southwest Victoria, or northern Victoria). Associations with milk protein concentration fitted as a continuous variable were assessed with and without adjustment for milk fat concentration for the same stage of lactation. This adjustment was of interest as, in the current study, milk protein concentration was correlated with milk fat concentration within each stage of lactation, as has been reported for the whole of lactation (Schutz et al., 1990; Welper and Freeman, 1992). Consequently, effects of milk protein concentration on reproductive performance independent of effects of milk fat concentration were of interest. Numbers of lactations in subgroups and crude percentages describing reproductive performance in each subgroup are reported; adjusted percentages are also reported. These were calculated using the crude percentages for the reference categories. These were transformed to odds, multiplied by the adjusted odds ratios, and the products back-transformed to the probability scale.

Effects of conception date on milk protein concentration were assessed using lactations where the cow conceived by $200 \mathrm{~d}$ after calving. Milk protein concentration was plotted against DIM by calving to conception category (50 d or less, 51 to $100 \mathrm{~d}, 101$ to $150 \mathrm{~d}$, and 151 to $200 \mathrm{~d}$ ) using locally weighted regression with Stata's lowess command; bandwidth was 0.8. Runningline least-squares smoothing was used with the tricube weighting function.

For some of these analyses, the outcome event would have occurred for some lactations after milk protein concentration was assessed. This is of less concern when using milk protein concentration as an indicator of reproductive performance. It was, however, desirable to also assess associations between milk protein concentration during each cow's breeding period and the subsequent daily hazard of conception to indirectly improve understanding of the underpinning causal mechanisms. Hazard functions described the probability of conception on each day of the breeding period for cows that had not conceived by that day. Only milk protein concentrations before each cow's conception day were used; thus, results were not affected by effects of pregnancy on milk protein concentration. Survival analyses were used with milk protein concentration during the cow's breeding period fitted as a time-varying covariate. For the first day of the breeding period, milk protein concentration was assumed to be as measured at the most recent test day before or on that day. For 
Table 2. Distribution of milk protein concentrations (\%) by stage of lactation ${ }^{1}$

\begin{tabular}{|c|c|c|c|c|c|c|c|c|c|}
\hline $\begin{array}{l}\text { Stage of } \\
\text { lactation (d) }\end{array}$ & $\begin{array}{l}\text { No. of } \\
\text { lactations }\end{array}$ & Minimum & $\begin{array}{c}1 \text { st } \\
\text { percentile }\end{array}$ & $\begin{array}{c}\text { 10th } \\
\text { percentile }\end{array}$ & Median & Mean $^{2}$ & $\begin{array}{c}\text { 90th } \\
\text { percentile }\end{array}$ & $\begin{array}{c}\text { 99th } \\
\text { percentile }\end{array}$ & Maximum \\
\hline 0 to 30 & 36,570 & 1.02 & 2.62 & 2.92 & 3.31 & 3.38 & 3.89 & 4.78 & 7.98 \\
\hline 31 to 60 & 47,363 & 1.04 & 2.50 & 2.79 & 3.13 & 3.13 & 3.48 & 3.83 & 6.43 \\
\hline 91 to 120 & 44,926 & 1.89 & 2.60 & 2.87 & 3.22 & 3.23 & 3.61 & 3.98 & 5.38 \\
\hline 121 to 150 & 42,579 & 0.14 & 2.65 & 2.92 & 3.27 & 3.29 & 3.68 & 4.05 & 7.83 \\
\hline 151 to 180 & 44,835 & 1.16 & 2.69 & 2.96 & 3.30 & 3.32 & 3.71 & 4.09 & 7.19 \\
\hline 241 to 270 & 37,902 & 1.12 & 2.81 & 3.13 & 3.54 & 3.57 & 4.05 & 4.57 & 6.30 \\
\hline 271 to 300 & 29,060 & 1.18 & 2.87 & 3.19 & 3.64 & 3.66 & 4.17 & 4.75 & 7.89 \\
\hline
\end{tabular}

${ }^{1}$ Only lactations where the cow's status for pregnancy by wk 6 could be determined; milk protein concentrations recorded as $\geq 8 \%$ were excluded. ${ }^{2}$ Each mean differed significantly (Bonferroni-adjusted $P<0.001$ ) from each other mean other than 0 to $30 \mathrm{~d}$ versus 181 to $210 \mathrm{~d}$, where Bonferroni-adjusted $P=1.000$.

subsequent days of the breeding period, milk protein concentrations were assumed to be as measured at the most recent previous test day. Cows were at risk of conception from the first day of the breeding period or, for cows with no test days before or on the first day of the breeding period, from their first test day during the breeding period. Cows not conceiving (i.e., those with no positive pregnancy diagnoses) were rightcensored at the end of the herd breeding period, d 147 of the herd breeding period or $28 \mathrm{~d}$ before their most recent pregnancy diagnosis, whichever occurred first. Lactations were excluded where the cow calved on or after the start of the herd breeding period, conceived or was right-censored before the start of the herd breeding period, or had no test days before conceiving. Cox proportional hazards models were fitted using Stata's stcox command, with milk protein concentration during the breeding period (varying over time), cow age at calving, source of data, year of breeding period start date, and interval from calving to breeding period start date (linear and quadratic terms) fitted as fixed effects. Herd was fitted as a gamma shared frailty and the Breslow method for ties was used (Breslow, 1974). In additional models, milk protein concentrations at the first test day from 0 to $30 \mathrm{~d}$ of lactation and at the first test day from 31 to $60 \mathrm{~d}$ of lactation (both before the breeding period) were also included as covariates for lactations where these were available (i.e., for cows calved longer before the start of the breeding period). As milk protein concentrations at the most recent test day before or on the first day of the breeding period were used to determine concentrations early in the breeding period, these test days were not used when determining milk protein concentrations at the first test day from 0 to 30 $\mathrm{d}$ of lactation and at the first test day from 31 to $60 \mathrm{~d}$ of lactation. The proportional hazards assumption for milk protein concentration during the breeding period (i.e., the assumption that the hazard ratio for the ef- fect of milk protein concentration during the breeding period was constant over time) was assessed by visual inspection of scatterplots and lowess smoothed plots of scaled Schoenfeld residuals versus time and from $P_{-}$ values for testing the null hypotheses that the slopes were zero over time, both generated using Stata's estat phtest command.

\section{RESULTS}

\section{Milk Protein Concentrations and Correlations Between Stages of Lactation}

The distributions of milk protein concentrations by stage of lactation are shown in Table 2. Milk protein concentrations varied widely but most were between 2.75 and $3.75 \%$. Median and mean concentrations declined after 0 to $30 \mathrm{~d}$ then increased steadily with stage of lactation.

Correlation coefficients for correlations in milk protein concentrations between various stages of lactation are shown in Table 3. Each of these was calculated using between 14,998 and 35,895 lactations. Correlations were closest between adjoining stages of lactation. The weakest correlations were with milk protein concentration from d 0 to 30 of lactation. For other stages of lactation, those more widely separated had correlation coefficients of 0.41 to 0.46 compared with 0.45 to 0.74 for closer stages.

\section{Associations Between Milk Protein and Reproductive Measures}

Associations between milk protein concentrations at most stages of lactation and the binary reproductive performance measures were generally approximately linear in the logit over the range of the most common concentrations of 2.75 to $3.75 \%$. Accordingly, estima- 
Table 3. Pearson correlation coefficients for correlations between milk protein concentrations at various stages of lactation

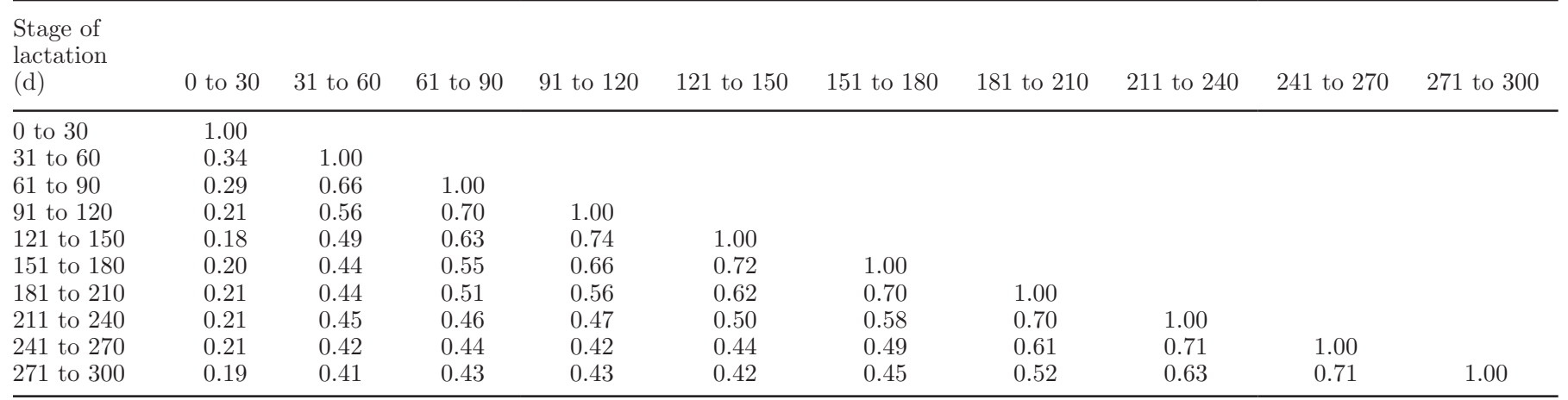

tion of strengths of association for a 1-percentage-point increase in milk protein concentration was appropriate. These estimates are summarized in Tables 4, 5, 6, and 7. The weakest associations were during the earliest period in the lactation (0 to $30 \mathrm{~d})$, and associations were generally strongest from d 31 to 150 of lactation. Estimated associations for d 31 to 60 were stronger than for 0 to $30 \mathrm{~d}$, but only slightly stronger than for subsequent stages of lactation.

Strengths of associations for conception to first service, pregnant by wk 6, and pregnant by wk 21 increased progressively with the stage of lactation for milk protein concentrations measured after d 180 of lactation. In contrast, associations for submission by wk 3 were progressively weaker with increasing stages of lactation.

Within each stage of lactation, milk protein concentration was correlated with fat concentration. Pearson correlation coefficients for 0 to 30,31 to 60,61 to 90 , and so on to 271 to $300 \mathrm{~d}$ were, respectively, $0.35,0.23$, $0.31,0.35,0.36,0.39,0.46,0.54,0.57$, and 0.57 . Numbers of lactations for these estimates were as shown in Table 2. Estimated strengths of association for a 1-percentage-point increase in milk protein concentration adjusted for fat concentration, and details of associations between milk protein concentrations fitted as categorical variables, are shown in Supplemental Tables S1 to S4 (http://dx.doi.org/10.3168/jds.201611276). Adjustment for milk fat concentration did not substantially alter estimation of strengths of association for a 1-percentage-point increase in milk protein concentration.

Associations with milk protein concentration were also assessed with milk protein concentration categorized into quintiles (Table 8 and Supplemental Tables S1 to S4; http://dx.doi.org/10.3168/jds.2016-11276). Reproductive performance was generally incrementally improved with each higher milk protein concentration category, except from the fourth to the highest quintile in some cases. These results were generally consistent with an approximately linear increase in reproductive performance for each additional percentage point increase in milk protein concentration, at least up to the highest quintile.

Table 4. Strengths of association for a 1-percentage-point increase in milk protein concentration measured at various stages of lactation on odds of submission by wk 3

\begin{tabular}{lccc}
\hline $\begin{array}{l}\text { Stage of lactation } \\
\text { (d) when milk protein } \\
\text { concentration measured }\end{array}$ & $\begin{array}{c}\text { Adjusted } \\
\text { odds ratio }^{1}\end{array}$ & $95 \%$ CI & $P$-value \\
\hline 0 to 30 & 1.22 & 1.15 to 1.30 & $<0.001$ \\
31 to 60 & 1.81 & 1.66 to 1.98 & $<0.001$ \\
61 to 90 & 1.72 & 1.58 to 1.88 & $<0.001$ \\
91 to 120 & 1.67 & 1.52 to 1.82 & $<0.001$ \\
121 to 150 & 1.72 & 1.58 to 1.88 & $<0.001$ \\
151 to 180 & 1.70 & 1.56 to 1.84 & $<0.001$ \\
181 to 210 & 1.50 & 1.38 to 1.63 & $<0.001$ \\
211 to 240 & 1.46 & 1.36 to 1.58 & $<0.001$ \\
241 to 270 & 1.28 & 1.19 to 1.38 & $<0.001$ \\
271 to 300 & 1.30 & 1.19 to 1.41 & $<0.001$ \\
\hline
\end{tabular}

${ }^{1}$ Adjusted for cow's age at calving, source of data, year of breeding period start date, and interval from calving to breeding period start date (linear and quadratic terms); herd was fitted as a random effect. 
Table 5. Strengths of association for a 1-percentage-point increase in milk protein concentration measured at various stages of lactation on odds of conception to first service

\begin{tabular}{lccc}
\hline $\begin{array}{l}\text { Stage of lactation } \\
\text { (d) when milk protein } \\
\text { concentration measured }\end{array}$ & $\begin{array}{c}\text { Adjusted } \\
\text { odds ratio }^{1}\end{array}$ & $95 \%$ CI & $P$-value \\
\hline 0 to 30 & 1.15 & 1.09 to 1.22 & $<0.001$ \\
31 to 60 & 1.41 & 1.30 to 1.53 & $<0.001$ \\
61 to 90 & 1.36 & 1.25 to 1.47 & $<0.001$ \\
91 to 120 & 1.36 & 1.26 to 1.48 & $<0.001$ \\
121 to 150 & 1.36 & 1.25 to 1.47 & $<0.001$ \\
151 to 180 & 1.21 & 1.12 to 1.31 & $<0.001$ \\
181 to 210 & 1.19 & 1.10 to 1.28 & $<0.001$ \\
211 to 240 & 1.38 & 1.29 to 1.49 & $<0.001$ \\
241 to 270 & 1.50 & 1.40 to 1.60 & $<0.001$ \\
271 to 300 & 1.66 & 1.54 to 1.78 & \\
\hline
\end{tabular}

${ }^{1}$ Adjusted for cow's age at calving, source of data, year of breeding period start date, and calving to first service interval (linear and quadratic terms); herd was fitted as a random effect.

\section{Effects of Stage of Lactation and Calving to Conception Interval}

Locally weighted regression plots of milk protein concentration by stage of lactation are shown in Figure 1. In early lactation, milk protein concentrations were highest for cows that conceived soonest after calving. Milk protein concentrations declined to approximately d 60 to 70 of lactation, then increased for the remainder of lactation, with greatest rates of increase for cows that conceived sooner after calving. The rate of increase was slightly higher from d 150 for cows that conceived $50 \mathrm{~d}$ or less after calving (mean calving to conception interval for 4,142 study lactations: $40.1 \mathrm{~d}$ ) compared with those that conceived 51 to $100 \mathrm{~d}$ after calving (mean calving to conception interval for 35,581 study lactations: $78.8 \mathrm{~d}$ ). These observations indicate that pregnancy was associated with small increases in milk protein concentration from approximately $110 \mathrm{~d}$ of gestation.

\section{Associations of Milk Protein Concentration During Breeding and Hazard of Conception}

Effects of milk protein concentration during the breeding period were assessed without and with adjustment for milk protein concentration over d 0 to 30 and 31 to 60 of lactation (Table 9 and Figure 2). There were 61,237 lactations from 62 herds that met the selection criteria for these analyses and all were included in these analyses. Of these lactations, intervals from calving to start of the breeding period were $>90$ d (4\%), 61 to $90 \mathrm{~d}(51 \%), 31$ to $60 \mathrm{~d}(33 \%)$ and 1 to 30 d (12\%). Further lactations were excluded when milk protein concentrations in $\mathrm{d} 0$ to 30 and 31 to 60 of lactation were fitted, as these data were not available for all lactations (Table 9). Milk protein concentration during the breeding period was positively associated with daily hazard of conception without and with these adjustments; estimated hazard ratios were 1.18 to 1.27. After adjusting for milk protein concentrations during

Table 6. Strengths of association for a 1-percentage-point increase in milk protein concentration measured at various stages of lactation on odds of pregnancy by wk 6

\begin{tabular}{lccc}
\hline $\begin{array}{l}\text { Stage of lactation } \\
\text { (d) when milk protein } \\
\text { concentration measured }\end{array}$ & $\begin{array}{c}\text { Adjusted } \\
\text { odds ratio }^{1}\end{array}$ & $95 \%$ CI & P-value \\
\hline 0 to 30 & 1.22 & 1.16 to 1.28 & $<0.001$ \\
31 to 60 & 1.67 & 1.55 to 1.80 & $<0.001$ \\
61 to 90 & 1.62 & 1.50 to 1.75 & $<0.001$ \\
91 to 120 & 1.65 & 1.52 to 1.78 & $<0.001$ \\
121 to 150 & 1.61 & 1.49 to 1.73 & $<0.001$ \\
151 to 180 & 1.44 & 1.34 to 1.55 & $<0.001$ \\
181 to 210 & 1.31 & 1.22 to 1.41 & $<0.001$ \\
211 to 240 & 1.47 & 1.37 to 1.57 & $<0.001$ \\
241 to 270 & 1.63 & 1.53 to 1.73 & $<0.001$ \\
271 to 300 & 1.83 & 1.70 to 1.96 & \\
\hline
\end{tabular}

${ }^{1}$ Adjusted for cow's age at calving, source of data, year of breeding period start date, and interval from calving to breeding period start date (linear and quadratic terms); herd was fitted as a random effect. 
Table 7. Strengths of association for a 1-percentage-point increase in milk protein concentration measured at various stages of lactation on odds of pregnancy by wk 21

\begin{tabular}{lccc}
\hline $\begin{array}{l}\text { Stage of lactation } \\
\text { (d) when milk protein } \\
\text { concentration measured }\end{array}$ & $\begin{array}{c}\text { Adjusted } \\
\text { odds ratio }^{1}\end{array}$ & $95 \%$ CI & \\
\hline 0 to 30 & 1.18 & 1.11 to 1.25 & $<$-value \\
31 to 60 & 1.56 & 1.42 to 1.71 & $<0.001$ \\
61 to 90 & 1.49 & 1.36 to 1.64 & $<0.001$ \\
91 to 120 & 1.38 & 1.25 to 1.52 & $<0.001$ \\
121 to 150 & 1.53 & 1.39 to 1.68 & $<0.001$ \\
151 to 180 & 1.44 & 1.32 to 1.58 & $<0.001$ \\
181 to 210 & 1.46 & 1.33 to 1.60 & $<0.001$ \\
211 to 240 & 1.71 & 1.57 to 1.87 & $<0.001$ \\
241 to 270 & 1.73 & 1.59 to 1.88 & $<0.001$ \\
271 to 300 & 2.02 & 1.84 to 2.21 & $<0.001$ \\
\hline
\end{tabular}

${ }^{1}$ Adjusted for cow's age at calving, source of data, year of breeding period start date, and interval from calving to breeding period start date (linear and quadratic terms); herd was fitted as a random effect.

the breeding period, concentrations in d 0 to 30 and 31 to 60 of lactation and before the start of the breeding period were also positively associated with daily hazard of conception but estimated hazard ratios were smaller (1.10 to 1.14) than for effect estimates for milk protein concentration during the breeding period. Predicted probabilities of nonpregnancy (survival functions) associated with various milk protein concentrations during the breeding period are shown in Figure 2. After adjusting for milk protein concentration in d 0 to 30 of lactation, milk protein concentration during the breeding period of $4.0 \%$ was associated with considerably reduced probabilities of nonpregnancy compared with concentrations of 2.5 and $3.0 \%$. P-values for assessing the proportional hazards assumptions were all $\leq 0.001$, but plots of Schoenfeld residuals versus time indicated that the hazard ratios for the effect of milk protein concentration during the breeding period were similar over time. Effect estimates for milk protein concentration during the breeding period (models 2, 3 and 4; Table 9) were predominantly based on milk protein concentrations after d 60 of lactation. For models 2, 3 and 4, respectively, 160 of $43,729,4$ of 20,003, and 0 of 8,514 milk protein concentrations during the breeding period were measured before d 60 of lactation.

\section{DISCUSSION}

One key finding from our study was that the beneficial associations between milk protein concentrations and each of the 4 selected indices for reproductive performance were evident when milk protein concentrations were measured in each $30-\mathrm{d}$ period from calving up to 300 DIM (Tables 4 to 7 ). Within the first $150 \mathrm{~d}$ of lactation, the adjusted odds ratios were highest from 31 to $60 \mathrm{~d}$ and only slightly lower up to $150 \mathrm{~d}$ of lactation. Estimated associations for d 31 to 60 were stronger than for d 0 to 30. Milk protein concentrations from 0 to $30 \mathrm{~d}$ of lactation were not as closely correlated with concentrations measured at subsequent 30-d intervals; closer correlations were evident between all of the other nine 30 -d periods studied.

The second key finding was that milk protein concentrations during the breeding period were positively associated with the daily hazard of conception. This effect was independent of milk protein concentrations in d 0 to 30 and 31 to 60 of lactation (when measured before the start of the breeding period), and, compared with these latter concentrations, milk protein concentration during the breeding period was more strongly associated with daily hazard of conception.

Table 8. Strengths of association between milk protein concentration (milk protein \%) measured 31 to $60 \mathrm{~d}$ after calving and pregnancy by wk 6

\begin{tabular}{|c|c|c|c|c|c|c|}
\hline Milk protein $\%$ & No. cows & $\begin{array}{c}\text { Crude } \% \text { pregnant } \\
\text { by wk } 6\end{array}$ & $\begin{array}{l}\text { Adjusted } \\
\text { odds ratio }^{1}\end{array}$ & $95 \%$ CI & $P$-value & $\begin{array}{c}\text { Adjusted } \% \text { pregnant } \\
\text { by wk } 6^{1}\end{array}$ \\
\hline$\leq 2.90$ & 9,156 & 41.0 & 0.80 & 0.75 to 0.85 & $<0.001$ & 43.1 \\
\hline 3.19 to 3.34 & 9,613 & 52.1 & 1.11 & 1.05 to 1.18 & 0.001 & 51.3 \\
\hline$>3.35$ & 9,677 & 55.2 & 1.20 & 1.13 to 1.27 & $<0.001$ & 53.2 \\
\hline Total & 47,363 & 48.7 & & & & \\
\hline
\end{tabular}

${ }^{1}$ Adjusted for cow's age at calving, source of data, year of breeding period start date, and interval from calving to breeding period start date (linear and quadratic terms); herd was fitted as a random effect. 


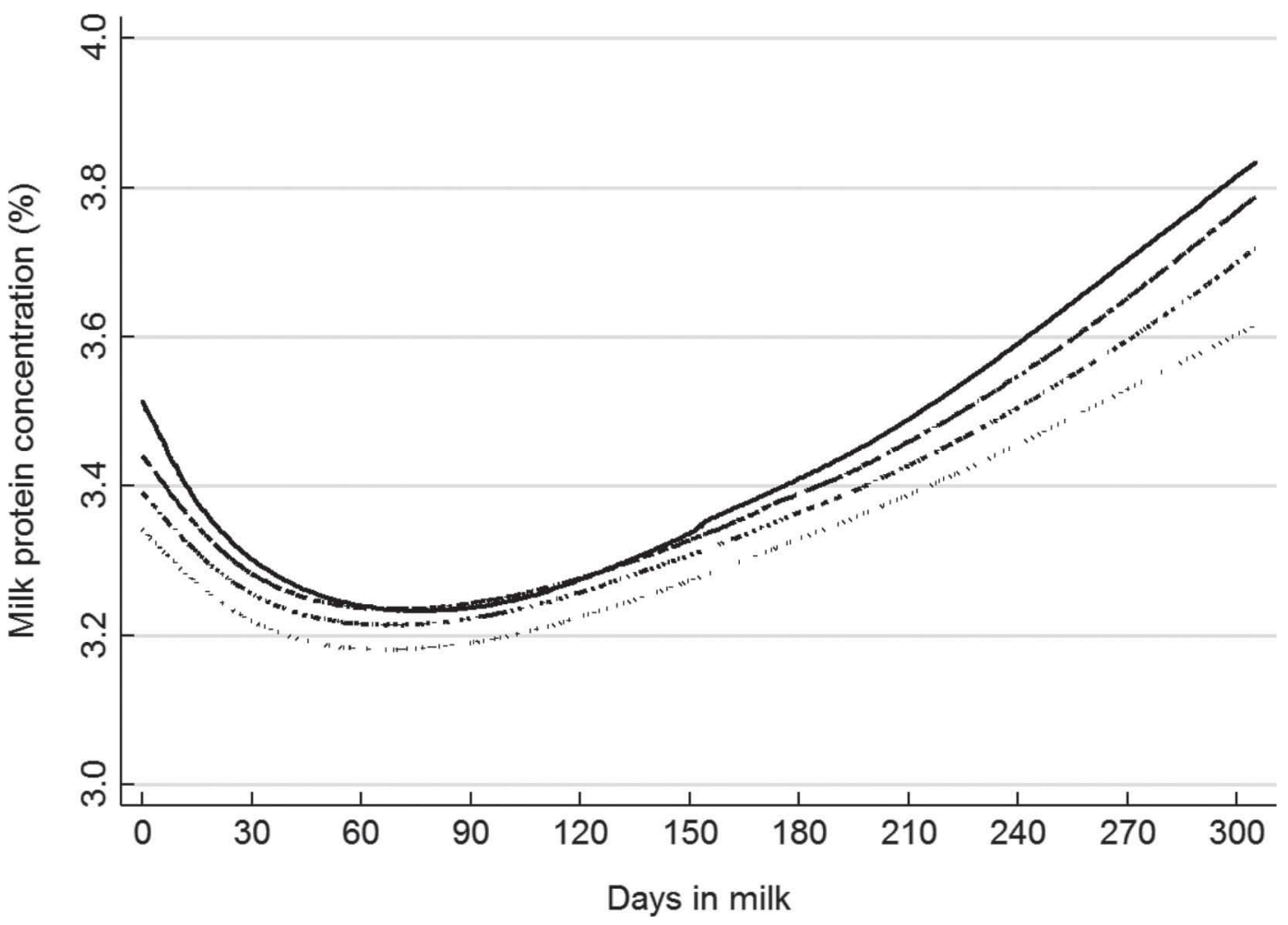

Figure 1. Locally weighted regression plots of milk protein concentration by stage of lactation (days in milk) for test days in lactations where the cow conceived (from top to bottom): in the first $50 \mathrm{~d}$ of lactation (solid line); 51 to $100 \mathrm{~d}$ after calving (long dash); 101 to $150 \mathrm{~d}$ after calving (short dash); or 151 to $200 \mathrm{~d}$ after calving (dotted).

These results collectively indicate that the association between milk protein concentration and reproductive performance is probably due, in part, to factors that affect milk protein concentration in mid and late lactation. Thus, the association is not entirely due to extent of negative energy balance in early lactation, as relatively few cows would be expected to have been in marked negative energy balance beyond d 60 of lactation (de Vries and Veerkamp, 2000; Coffey et al., 2004; Friggens et al., 2007; Pedernera et al., 2008), and negative energy balance in early lactation is unlikely to markedly affect milk protein concentration in mid

Table 9. Ratios of daily hazards of conception during the breeding period for 1-percentage-point increases in milk protein concentrations measured before and during the breeding period

\begin{tabular}{|c|c|c|c|}
\hline $\begin{array}{l}\text { Stage of lactation when milk protein } \\
\text { concentration measured }\end{array}$ & $\begin{array}{c}\text { Adjusted } \\
\text { hazard ratio }\end{array}$ & $95 \% \mathrm{CI}$ & $P$-value \\
\hline \multicolumn{4}{|c|}{ Model 1 ( $\mathrm{n}=61,237$ lactations from 62 herds) } \\
\hline During the breeding period & 1.20 & 1.17 to 1.24 & $<0.001$ \\
\hline \multicolumn{4}{|c|}{ Model $2(\mathrm{n}=18,733$ lactations from 50 herds $)$} \\
\hline Days 0 to 30 of lactation ${ }^{2}$ & 1.10 & 1.06 to 1.14 & $<0.001$ \\
\hline During the breeding period & 1.24 & 1.16 to 1.32 & $<0.001$ \\
\hline \multicolumn{4}{|c|}{ Model $3(\mathrm{n}=9,627$ lactations from 42 herds) } \\
\hline Days 31 to 60 of lactation ${ }^{2}$ & 1.11 & 1.00 to 1.23 & 0.059 \\
\hline During the breeding period & 1.27 & 1.14 to 1.42 & $<0.001$ \\
\hline \multicolumn{4}{|c|}{ Model 4 ( $\mathrm{n}=3,712$ lactations from 25 herds) } \\
\hline Days 0 to 30 of lactation ${ }^{2}$ & 1.12 & 1.01 to 1.22 & 0.014 \\
\hline Days 31 to 60 of lactation ${ }^{2}$ & 1.14 & 0.94 to 1.39 & 0.183 \\
\hline During the breeding period & 1.18 & 0.98 to 1.41 & 0.080 \\
\hline
\end{tabular}

${ }^{1}$ Adjusted for cow's age at calving, source of data, year of breeding period start date, and interval from calving to breeding period start date (linear and quadratic terms); herd was fitted as a shared frailty; for models 2,3 and 4, milk protein concentration in d 0 to 30 and 31 to 60 of lactation were also fitted as indicated.

${ }^{2}$ Only lactations where milk protein concentration had been measured in this stage of lactation and before the breeding period were included. 
and late lactation (Gross et al., 2011). In an Australian study with cows fed a pasture-based diet with or without a partial mixed ration, daily negative energy balance was most extreme, on average, at wk 2 to 3 of lactation (Pedernera et al., 2008). Negative energy balance is most extreme in the first 20 to $30 \mathrm{~d}$ of lactation in housed cows (de Vries and Veerkamp, 2000; Coffey et al., 2004; Friggens et al., 2007); however, it is possible that energy balance accounts for some of the relationship as magnitude and direction of energy balance can vary within and between cows throughout lactation.

When milk protein concentration was measured after d 180 of lactation, strengths of associations increased progressively with the stage of lactation for conception to first service, pregnant by wk 6 , and pregnant by wk 21. These increases were probably due to effects of pregnancy on milk protein concentration as advancing pregnancy caused small increases in milk protein concentration from approximately $110 \mathrm{~d}$ of gestation (Figure 1). Roche (2003) also detected small increases in milk protein concentration due to pregnancy as milk protein concentration in pregnant cows in seasonally calving herds increased more rapidly than in nonpregnant cows from wk 25 to 26 of lactation, coinciding with approximately d 91 to 98 of gestation. In contrast, for submission by wk 3, associations were progressively weaker with increasing stages of lactation. As relationships between submission by wk 3 and milk protein concentration would not be directly altered by effects of pregnancy on milk protein concentration, this also supports our conclusion that these increases in odds ratios when milk protein concentration was measured after d 180 of lactation were probably due to effects of pregnancy on milk protein concentration. In contrast, our survival analyses were not affected by effects of pregnancy on milk protein concentration, as only milk protein concentrations before each cow's conception day were used.

As milk protein concentration was generally measured only once every 4 to $8 \mathrm{wk}$, our reported hazard ratios (from the survival analyses) were probably biased toward null (i.e., toward underestimation of the true hazard ratios). For these analyses, for the first day of the breeding period, milk protein concentration was

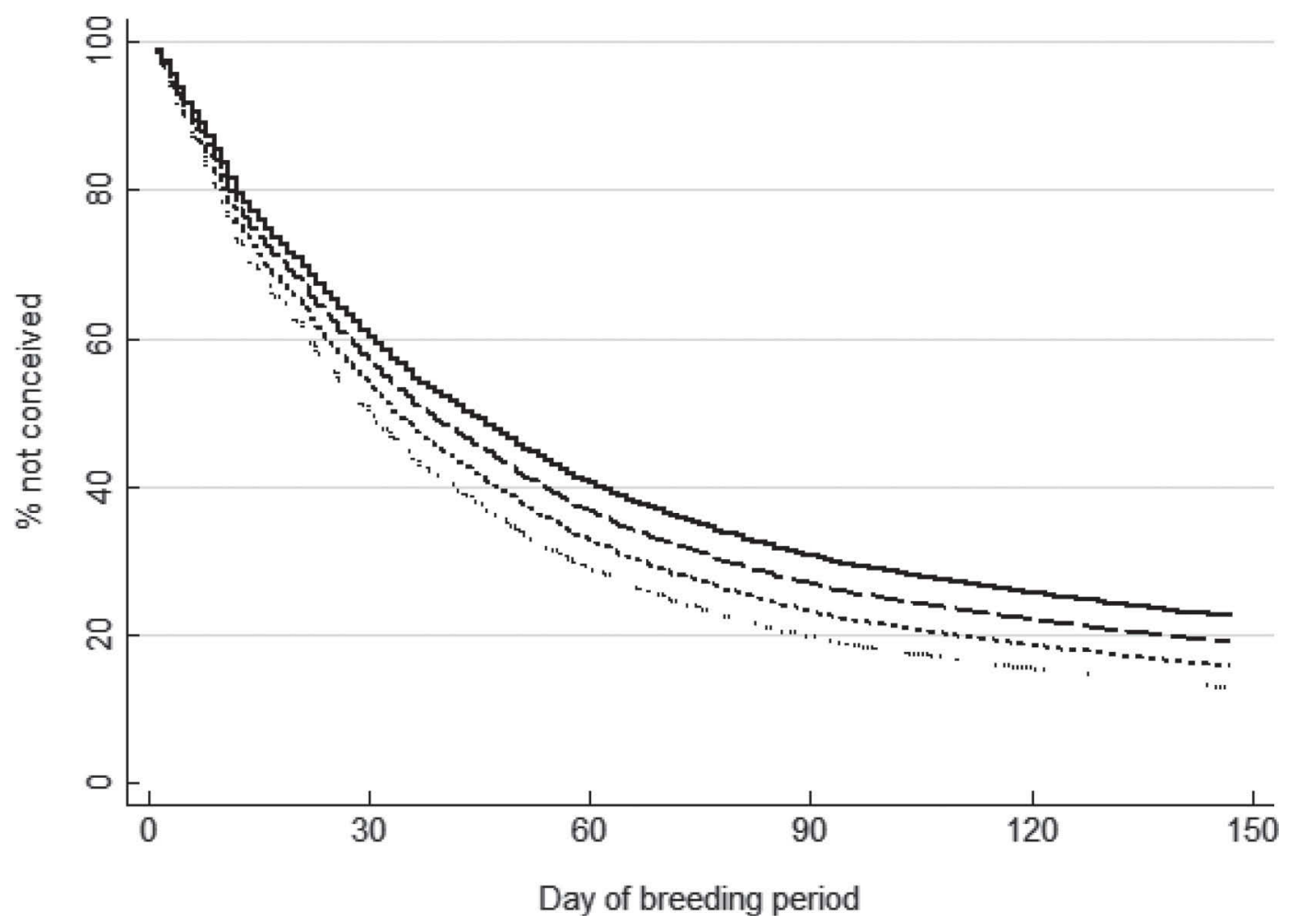

Figure 2. Predicted probabilities of nonconception (survival functions) by day of breeding period for various milk protein concentrations during the breeding period (from top to bottom): $4.0 \%$ (solid line); $3.5 \%$ (long dash); $3.0 \%$ (short dash); and 2.5\% (dotted). Predictions were adjusted for (and are at the mean values for) cow age at calving, source of data, year of breeding period start date, interval from calving to breeding period start date (linear and quadratic terms), and milk protein concentration in d 0 to 30 of lactation. Only lactations where milk protein concentration had been measured in d 0 to 30 of lactation and before the start of the breeding period were included. Herd was fitted as a shared frailty; all predictions were at a frailty of 1. 
assumed to be as measured at the most recent test day before or on that day. Of the 61,237 lactations used for model 1 (Table 9), for 52,397 lactations, the cow had a test day before or on the first day of the breeding period. For these cows, the median intervals from that test day to the start of the breeding and to the first test day in the breeding period were 16 and 33 d, respectively. For subsequent days of the breeding period, milk protein concentrations were assumed to be as measured at the most recent previous test day. Thus, for the 61,237 lactations used for model 1 (Table 9), the median of the intervals between test days during the breeding periods and intervals from most recent previous test day to conception or right-censoring date was 27.5 d. Differences between assumed and actual milk protein concentrations on particular days of the breeding period probably increased with longer times since milk protein concentration was measured. As these measurement errors were likely to have been nondifferential (i.e., unrelated to conception date), this will have tended to bias our reported hazard ratios toward null (i.e., toward underestimation of the true hazard ratios).

Results from the current study show that milk protein concentrations from 0 to $30 \mathrm{~d}$ of lactation are not as strongly associated with reproductive performance as concentrations from 31 to 60 d. Madouasse et al. (2010) also reported that milk protein concentrations measured at the second test date after calving were more strongly associated with reproductive performance (calving to conception interval in their study) than milk protein concentration at first test. Milk protein concentrations from 0 to $30 \mathrm{~d}$ of lactation were less closely correlated with concentrations measured at subsequent 30-d intervals (Table 3 ), with correlation coefficients from 0.19 to 0.34. In contrast, correlation coefficients between all of the other nine 30-d periods up to 300 DIM ranged from 0.41 to 0.78 . Haile-Mariam and Goddard (2008) also reported lower phenotypic correlation coefficients between early-lactation measures of milk protein concentration and measures later in lactation. Silvestre et al. (2009) reported that early-lactation measures of milk protein concentration were the most variable, and Quinn et al. (2006) found that these were predicted less accurately than at other stages of lactation by standard equations for the whole of lactation. From our collective findings, we conclude that factors determining milk protein concentration during the first $30 \mathrm{~d}$ of lactation are not identical to the causes of milk protein concentration later in lactation, and that some of the latter causes of milk protein concentration may be more closely related to the underlying mechanisms causing the milk protein concentration-reproductive performance relationship.

The results of the current study show that the beneficial associations between milk protein concentrations and 4 selected measures of reproductive performance can be demonstrated from single test-day results throughout lactation; this may be due to the high heritability of milk protein concentration. Haile-Mariam and Goddard (2008) recorded heritabilities in Holstein cows in Australian herds ranging from 0.41 for early-lactation estimates to 0.58 in late lactation. The occurrence of the associations between milk protein concentrations assessed throughout lactation and reproductive performance also explains why the association has been reported in studies that have used a wide range of times or periods from single dates to whole-lactation averages for measuring milk protein concentration. This indicates that cows whose reproductive performance is more likely to be enhanced by factors associated with milk protein concentration can be identified based on a single test-day result throughout lactation.

\section{CONCLUSIONS}

Our results indicate that the association between milk protein concentration and reproductive performance is probably partly due to factors other than extent of negative energy balance in early lactation. However, it is possible that energy balance accounts for some of the relationship, as magnitude and direction of energy balance can vary within and between cows throughout lactation. Milk protein concentrations from a single test day of lactation predicts subpopulations of cows with differing average reproductive performance; milk protein concentrations measured after d 30 of lactation are more useful than concentrations measured in the first $30 \mathrm{~d}$ for identifying these subpopulations. Further research is required to identify the causes of these associations.

\section{ACKNOWLEDGMENTS}

We gratefully acknowledge the assistance of the veterinarians who supplied data for this study: Jakob Malmo (Maffra Veterinary Centre, Maffra, Victoria, Australia), Peter Younis and David Colson (The Vet Group, Timboon and Allansford, Victoria, Australia), Steve Jagoe (Warrnambool Veterinary Clinic, Warrnambool, Victoria, Australia), and Neil Leighton (Smithton Veterinary Services, Smithton, Tasmania, Australia), and the Australian Dairy Herd Improvement Scheme (ADHIS, Melbourne, Victoria, Australia) and Paul Koh in particular, who supplied data from the ADHIS database. This study was partly funded by Department of Economic Development, Jobs, Transport and Resources, Government of Victoria, Victoria, Australia. 


\section{REFERENCES}

Breslow, N. 1974. Covariance analysis of censored survival data. Biometrics 30:89-99.

Buckley, F., K. O'Sullivan, J. F. Mee, R. D. Evans, and P. Dillon. 2003. Relationships among milk yield, body condition, cow weight, and reproduction in spring-calved Holstein-Friesians. J. Dairy Sci. $86: 2308-2319$

Canfield, R. W., C. J. Sniffen, and W. R. Butler. 1990. Effects of excess degradable protein on postpartum reproduction and energy balance in dairy cattle. J. Dairy Sci. 73:2342-2349.

Coffey, M. P., G. Simm, J. D. Oldham, W. G. Hill, and S. Brotherstone. 2004. Genotype and diet effects on energy balance in the first three lactations of dairy cows. J. Dairy Sci. 87:4318-4326.

Coulon, J. B., and B. Rémond. 1991. Variations in milk output and milk protein content in response to the level of energy supply to the dairy cow: A review. Livest. Prod. Sci. 29:31-47.

de Vries, M. J., and R. F. Veerkamp. 2000. Energy balance of dairy cattle in relation to milk production variables and fertility. J. Dairy Sci. 83:62-69.

Fahey, J., J. M. Morton, and K. L. Macmillan. 2003. Relationship between milk protein percentage and reproductive performance in Australian dairy cows. Proc. N.Z. Soc. Anim. Prod. 63:82-86.

Friggens, N. C., P. Berg, P. Theilgaard, I. R. Korsgaard, K. L. Ingvartsen, P. Løvendahl, and J. Jensen. 2007. Breed and parity effects on energy balance profiles through lactation: evidence of genetically driven body energy change. J. Dairy Sci. 90:5291-5305.

Garvin, J. K. 1999. The effect of dietary protein degradability and genetics on the protein quality of milk for cheese manufacture. PhD Thesis. Department of Animal Science, Faculty of Veterinary Science, University of Sydney, Sydney, Australia.

Grieve, D. G., S. Korver, Y. S. Rijpkema, and G. Hof. 1986. Relationship between milk composition and some nutritional parameters in early lactation. Livest. Prod. Sci. 14:239-254.

Gross, J., H. A. van Dorland, R. M. Bruckmaier, and F. J. Schwarz. 2011. Performance and metabolic profile of dairy cows during a lactational and deliberately induced negative energy balance with subsequent realimentation. J. Dairy Sci. 94:1820-1830.

Haile-Mariam, M., and M. E. Goddard. 2008. Genetic and phenotypic parameters of lactations longer than 305 days (extended lactations). Animal 2:325-335.

Hanigan, M. D., L. A. Crompton, B. J. Bequette, J. A. N. Mills, and J. France. 2002. Modelling mammary metabolism in the dairy cow to predict milk constituent yield, with emphasis on amino acid metabolism and milk protein production: Model evaluation. J. Theor. Biol. 217:311-330

Hanigan, M. D., L. A. Crompton, J. A. Metcalf, and J. France. 2001 Constituent yield, with emphasis on amino acid metabolism and milk protein production: Model construction. J. Theor. Biol. 213:223-239

Harris, B. L., and J. E. Pryce. 2004. Genetic and phenotypic relationships between milk protein percentage, reproductive performance and body condition score in New Zealand dairy cattle. Proc. N.Z. Soc. Anim. Prod. 64:127-131.
Lapierre, H., G. E. Lobley, L. Doepel, G. Raggio, H. Rulquin, and S. Lemosquet. 2012. Mammary metabolism of amino acids in dairy cows. J. Anim. Sci. 90:1708-1721.

Madouasse, A., J. N. Huxley, W. J. Browne, A. J. Bradley, I. L. Dryden, and M. J. Green. 2010. Use of individual cow milk recording data at the start of lactation to predict the calving to conception interval. J. Dairy Sci. 93:4677-4690.

Morton, J. M. 2004. Determinants of reproductive performance of dairy cows in commercial herds in Australia. PhD Thesis. Faculty of Veterinary Science, University of Melbourne, Melbourne, Australia. Accessed Oct. 15, 2015. http://hdl.handle.net/11343/38864.

Moss, N., I. J. Lean, S. W. J. Reid, and D. R. Hodgson. 2002. Risk factors for repeat-breeder syndrome in New South Wales dairy cows. Prev. Vet. Med. 54:91-103.

Opsomer, G., Y. T. Grohn, J. Hertl, M. Coryn, H. Deluyker, and A. de Kriuf. 2000. Risk factors for post partum ovarian dysfunction in high producing dairy cows in Belgium: A field study. Theriogenology $53: 841-857$.

Patton, J., D. A. Kenny, S. McNamara, J. F. Mee, F. P. O'Mara, M. G. Diskin, and J. J. Murphy. 2007. Relationships among milk production, energy balance, plasma analytes, and reproduction in Holstein-Friesian cows. J. Dairy Sci. 90:649-658.

Pedernera, M., S. C. García, A. Horagadoga, I. Barchia, and W. J. Fulkerson. 2008. Energy balance and reproduction on dairy cows fed to achieve low or high milk production on a pasture-based system. J. Dairy Sci. 91:3896-3907.

Quinn, N., L. Killen, and F. Buckley. 2006. Modelling fat and protein concentration curves for Irish dairy cows. Ir. J. Agric. Food Res. 45:13-23.

Reist, M., D. K. Erdin, D. von Euw, K. M. Tschumperlin, H. Leuenberger, H. M. Hammon, C. Morel, C. Philipona, Y. Zbinden, N Kunzi, and J. W. Blum. 2003. Postpartum reproductive function: association with energy, metabolic and endocrine status in high yielding dairy cows. Theriogenology 59:1707-1723.

Roche, J. R. 2003. Effect of pregnancy on milk production and bodyweight from identical twin study. J. Dairy Sci. 86:777-783.

Schutz, M. M., L. B. Hansen, G. R. Steuernagel, and J. K. Reneau. 1990. Genetic parameters for somatic cells, protein, and fat in milk of Holsteins. J. Dairy Sci. 73:494-502.

Silvestre, A. M., A. M. Martins, V. A. Santos, M. M. Ginja, and J. A. Colaço. 2009. Lactation curves for milk, fat and protein in dairy cows: A full approach. Livest. Sci. 122:308-313.

Welper, R. D., and A. E. Freeman. 1992. Genetic parameters for yield traits of Holsteins, including lactose and somatic cell score. J Dairy Sci. 75:1342-1348.

Xu, Z.Z., and L. Burton. 2003. Reproductive performance of dairy cows in New Zealand. Final Report of the Fertility Monitoring Project. Livestock Improvement, Hamilton, New Zealand p. 33. Accessed Oct. 15, 2015. http://www.lic.co.nz/user/file/Monitoring\%20 fertility\%20report\%20for\%20distribution.pdf.

Yang, L., N. Lopez-Villalobos, D. P. Berry, and T. Parkinson. 2009. Phenotypic relationships between milk protein percentage and reproductive performance in three strains of Holstein Friesian cows in Ireland. Proc. N.Z. Soc. Anim. Prod. 70:29-32. 